\title{
圈 \\ The Effect of The Fed's \\ Quantitative Easing Policy on the Performance of Listed Companies and the Banking Sector in Indonesia
}

\author{
Yanuar Rizky ${ }^{1}$
}

\begin{abstract}
While the efficient market hypothesis suggests that stock price reflects the fundamental condition of companies, which could affect investors' decisions, this technical note reports empirical evidence that stock price is also influenced by the public's perception of the market situation. This note shows that the source of funds circulating in the Indonesia Stock Exchange is related to excess liquidity resulting from the policy of quantitative easing (QE) by developed countries' central banks. Banks funding assets with debt results in leverage relationships with the Capital Adequacy Ratio (CAR) negatively affected. Thus it is evident that the Indonesian banking strategy is "reactive" and is influenced by external factors. External factors can be influenced by global issues as well as internal (enterprise performance) issues. Therefore foreign and global issues may be important (perhaps dominant) in determining the perceptions of the Indonesian stock market.
\end{abstract}

Keywords: Indonesian stock exchange, bank, quantitative easing.

JEL Code(s): E44, E58

\footnotetext{
${ }^{1}$ Doctoral Program - Strategic and Growth, Binus University, Jakarta, Indonesia
} 


\section{Introduction}

Since the 2008 financial crisis, awareness of the psychological elements of global macroeconomic conditions is increasing. The globalization of financial markets has made the relationship between customers and suppliers, more fluid and dynamic. It has also driven countries' fiscal and monetary policy to adapt to the structure of competition; also resources have become more influential which could add to the potential systemic risk of the financial condition of corporations.

From the corporation's (micro-) perspective, financial statements are the reflection of their activity. Financial reporting separates accounting theory into two structures, namely (1) the Balance Sheet, which illustrates the balance of assets that are mathematically derived from debt + capital; and (2) the Income Statement that describes the operations of corporations in gaining revenue and issuing expenses, the difference in net positive financial costs (debt and or dividends are distributed to shareholders) are a source of funds to strengthen their capital account in the balance sheet.

However, relations between limited assets derived from debt or capital, and capital from shareholders or retained earnings them is strongly influenced by the behaviour of the economy as a whole (macro structure) displayed in the figure below.

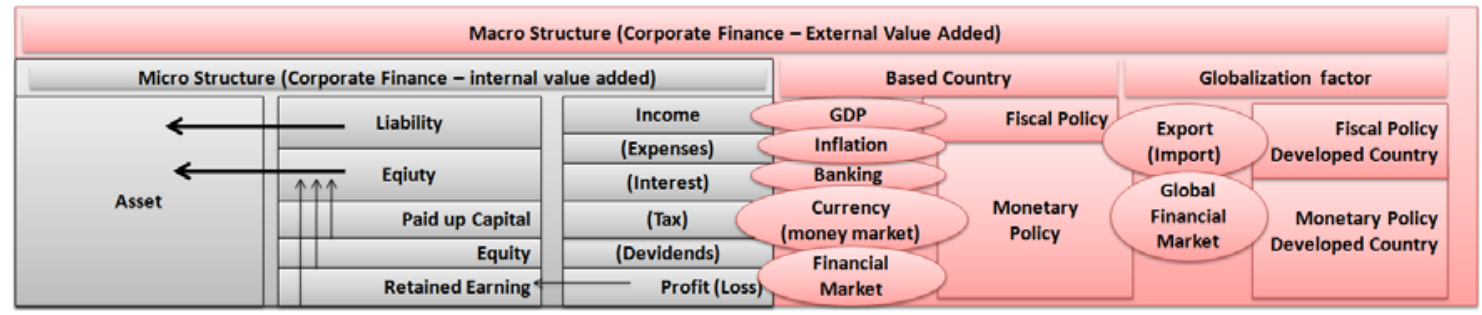

Figure 1: Structure of Macro - Micro

Following the 1998 crisis, Asian countries’ central banks (which were the crisis's epicentre) have played a more active role in setting monetary policy. This is also what happened to the US's central bank The Fed after the global financial crisis of 2008 when the US was the crisis's epicentre. The Fed has since played a more active monetary role. Indeed, the impact of this role has spread throughout the world. Schäffer et al (2011) found that many researchers on finance fail to pay due attention to the effect of The Fed's quantitative easing because they use too normative a research approach. These effects might be better understood if the "linkage theory" of the macro economy is used. The 1998 Asian crisis has led to Asian Central Banks being directed to actively influence market expectations (Siok, 2009). This becomes an important factor for corporate income, interest cost, and stock price expectations (Kyung, 2008).

\section{Literature Review}

Several studies have been dedicated to evaluating how research into financial strategy is conducted. Among them, Schäffer et al (2011) extensively reviews work on financial strategy before the 2008 financial crisis. They found evidence that the influence of macro and monetary policies within countries as the occurrence of vacancy factor to market behaviour. They also emphasise the dominance of competition among developed countries as the "body of knowledge" of strategic finance as a mean of risk assessment. Nevertheless, for the pre- 
crisis period, the study from Schäffer et al (2011) does not include the psychological elements of global macroeconomic conditions in their study. However, these elements should be considered as they could influence the behaviour of the whole global financial market.

A study from Kyung (2008) examines the effect of USD volatility on stock market condition in (South) East Asian countries. It employs statistical modelling to compare volatility with similar studies from Dumas and Solnik (1995); Bartov et al. (1996); De Santis and Gerard (1998); Aquino (2005, 2006); and Yau and Nieh (2006). The model shows that before the 1998 crisis, the impact of USD volatility on the stock market in developing countries was relatively small, and the correlation with the market in the US was quite strong. Nevertheless, when the crisis occurred, the condition of stock markets in the US is less affected by the volatility of USD, in comparison to the Asian countries which showed a large impact (Kyung, 2008).

The liquidity of financial markets that determines global money supply will affect inflation and thus economic growth, especially for developing countries which are very dependent on the exchange rate of their currency. Fluctuation and deterioration of exchange rates are very influential on prices and overall consumer purchasing power as was seen in the 1998 Asia crisis. The contagion effect of currency depreciation drove upward-spiralling inflation due to the position of imports, especially from the side of foreign capital, either through debt syndication and foreign banking or stock held in foreign capital markets. The aftermath was overall that economic indicators in the affected countries plunged. Moreover, exchange rate volatility against the USD also came from stock market pressure (as seen in the Philippines where the currency was relatively stable before the 1998 pressure occurred in Asian markets). Thus, stock market pressure can also be perceived as another source of the crisis (Aquino, 2005).

The 1998 Asian crisis has provided valuable lessons for developing countries. Exchange rate volatility not only led to deterioration of financial markets, but also triggered a banking crisis. This eventually led to de-industrialization in the developing countries which spurred inflation due to the position of imported goods. In the aftermath, most of the Asian countries in the epicentre of the crisis changed their exchange rate management policy, from fixed to floating rate. In addition, an ITF (inflation targeting framework) was also widely implemented. ITF focuses on managing interest rates as the mechanism to keep inflation within set targest.

However, a review of the implementation of ITF in ASEAN countries suggested that ITFs are not as successful as were claimed by Central Banks. Benchmark interest rates, which refers to the inflation target (ITF) was found to be less than effective as a buffer to provide stability against exchange rate volatility (Siok, 2009). When central banks control inflation expectations through their benchmark rates, then the monetary policy becomes a determinant factor in corporate financial strategies. This is the gap which is not found in most strategic finance literature before the 2008 financial crisis (Schaffer et al, 2011). Corporates tend to overlook factors that are affected by monetary policy (and exchange rates) in their financial strategy (Siok, 2009).

Siok (2009) points out that the benchmark interest rate policy of the Central Bank in developing countries that actively prevents inflation expectations (ITF) could not effectively reduce exchange rate volatility. This is because of the position of the post-inflationary crisis in developing countries, which are net importers due to de-industrialization of their corporate sector. The inflationary role (position) of imports of consumer goods has made the ITFs into 
ETFs (Exchange Targeting Framework). This was reflected in a research from six developing countries (Brazil, Chile, Mexico, Thailand, South Korea and the Czech Republic) showing the ITFs respond to the movement of the exchange rate rather than to inflation itself (Tahir, 2011).

Tahir (2011) also shows the risky position of developing countries due to exchange rate volatility such as led to the 1998 Asian crisis (Kyung, 2008). If inflation becomes vulnerable to exchange rate volatility, the ITF policy in developing countries would not be stable in the medium and long term, it would also tend to be expensive, or in other words, bear highinterest (Siok, 2009). The Central Bank interest rate fluctuations make significant impact on the sustainability of corporate financial posture (strategy) in three ways: (1) Fluctuation will raise interest rate making it difficult for expansion to take place; (2) Fluctuations in exchange rates and central bank intervention in the currency market will affect the volatility in the stock market, making the cost of capital higher. This will, in turn, increased shareholders' distress. (3) Consumers' and suppliers' purchasing power will be prone to unstable inflation.

Mainstream economists argue that one of the causes of the 2008 financial crisis was a "savings gap" from interest rate competition between the central banks of developed countries and developing countries. They also highlight the issue of the "currency war" launched by the developing countries that had not revalued their currency because of their capital control regime (with high interest rates) as another cause of the crisis (Liang, 2012).

In other words, Liang (2012) supports the research of Tahir (2011) that developing countries will resist the outflow of money by using high interest rates out of concerns about free foreign exchange regimes. Also, developing countries' central banks still intervene in money markets as short-term inflation therapy. Developing countries like China conduct progressive reabsorption of foreign funds into Asia through high interest rate instruments accompanied by "capital controls".

In response, developed countries are urged to lower global interest rates as proposed by Bernanke (the Fed chairman) at the Central Banks Governors Meeting in Frankfurt, 14 September 2007. However, developed countries actually employ similar strategies to control liquidity flow based on their interests. For instance, in 2002 Alan Greenspan cut interest rates after American banks absorbed funds from the 1998 Asian crisis. As stated by Liang (2012) saving imbalances affect the world since they are controlled by the rate war between states. Thus, Ben Bernanke in 2007 asked the Central Bank of each country to lower its interest rate, to stem the flow of funds to the United States (stimulated by the US's trade deficit to China since 2003). This was carried out by raising the Fed's rate. In Liang (2012), mainstream economists also argue that the interest rate war between central banks occurred not only due to the savings gap factor but also because countries like China employ capital control.

Adjustment to global imbalances by demanding changes be made by developing countries, while developed countries do not change their behaviour, has created volatility in global financial markets. This becomes problematic for monetary control in developing countries on the other side (Liang, 2012). Thus, the 2008 crisis was spurred in part by global imbalances when the reluctance of developed countries to control global inflation with the movement of money supply in the money market, met resistance by developing countries such as China to put a stop to the money supply in the financial market. This literature led to the conclusion that active monetary policy triggers the choice of corporate financial strategy. On the other hand, the monetary policy of developing countries is heavily influenced by developed countries' monetary policy. Thus, central bank policy is one of the main drivers of 
perceptions that determine the behaviour of actors in the financial markets in developing countries.

At the time when the crisis burst, negative perceptions developed in the media (both mainstream and social media) and were a strong influence leading the behaviour of financial markets for the worse, "bad news leads market volatility behaviour" (Casarin, 2013). The 2008 crisis was then followed by more active market intervention by the Fed. The Fed's policy in the market led to reabsorption of funds from developing countries (including in Asia) but not by using a higher interest rate through a "push-pull” policy money supply policy of USD in the global financial markets. The Fed's low interest policies, which spread US dollar funds to developing countries under the Fed's so-called "quantitative easing” (QE).

QE at first seemed a boon for emerging countries, whereby since its beginning in March 2009, the financial markets of developing countries were flooded by liquidity. But developing countries did not realise that when inflation increased, the Fed would not raise interest rates, but to the contrary, they lowered interest rates. This would not have been so problematic if the Fed's policy was low interest only, but there was also no control of the money supply out of the financial system. What happened is that money outflow was triggered by the Fed stimulus injecting USD into the market, through the purchase of US securities by the Fed.

Excess liquidity gained market participants, the control of "push-pull" policies of the Fed QE equal to the export of the financing crisis and inflation in the United States to other countries. This then triggered another three central banks that controlled the USD circulation in the foreign exchange basket of the IMF (SDR: Special Drawing Rights) to perform similar QE policy in US dollar money markets, the Bank of England (UK), BOJ (Japan), and the ECB (European Union). Control of money supply in the money market came under control of the G4 (the Fed, BOE, BOJ and ECB), which heavily influenced by the Fed. The flow of QE funds into developing countries created the psychological condition of the global financial markets being controlled by the interests of G4, which may be likely to call the money back (causing capital outflow) in greater supply than its inflow earlier (Morgan, 2011). Therefore, when the US economy recovers (which is financed from the volatility of global financial markets and supported by fiscal policy) the QE will stop because of the decline in the US fiscal deficit (QE will no longer be necessary).

A "tapering" issue has arisen since the third quarter of 2011 with its peak in 2013 which has sparked deterioration in financial markets of developing countries. This has caused excessive volatility in the financial markets over the US Dollar currencies of developing countries, including Indonesia. Based on research by Casarin and Squzzoni (2013) the 2008 financial crisis was preceded by the development of negative press coverage which was reflected in perceptions of market participants in the United States, which then triggered market deterioration. With the same logic, the Fed also seems to be encouraging the negative sentiment which drives deterioration of financial markets in developing countries. This clearly has implications for developing countries, since Asian crisis in 1998 was triggered by the volatility pressure of financial markets financial markets in developing countries (Kyung, 2008).

\section{Analysis}

Global Fund Relationships and Macro Economic Indicators in Indonesia

Empirical evidence suggests that the pressure of global funds into emerging capital markets is

characterized by a depressed position of the exchange rate. This then has an impact on 
national macroeconomic fundamentals. Correlation tests show (Indonesian macroeconomic data 2005-2010) that the negative pressure is mainly derived from stock price movements (IHSG) in Indonesia stock exchange as shown in Table 1.

\begin{tabular}{|c|c|c|c|c|c|c|c|c|c|c|}
\hline & correlations & Reserve Ballance & Inflation & Oil Export & Oil Import & Oil Price (OPEC) & Oil Price (US) & Oil Price (Libya) & Currency Rate & Stock Exchange Index \\
\hline \multirow[t]{3}{*}{ Reserve Ballance } & Pearson Correlations & 1 & \begin{tabular}{|l|}
0,867 \\
\end{tabular} & $\begin{array}{l}0,641 \\
\end{array}$ & 0,740 & $\begin{array}{r}0,802 \\
\end{array}$ & 0,745 & \begin{tabular}{|r|}
0,842 \\
\end{tabular} & $-0,830$ & 0,958 \\
\hline & Sig (2-talled) & - & 0,000 & 0,013 & 0,002 & 0,001 & 0,002 & 0 & 0,000 & 0,000 \\
\hline & $\mathrm{N}$ & 14 & 14 & 14 & 14 & 14 & 14 & 14 & 14 & 14 \\
\hline \multirow[t]{3}{*}{ Inflation } & Pearson Correlations & 0,867 & 1 & 0,398 & 0,528 & 0,571 & 0,513 & 0,616 & $-0,755$ & 0,841 \\
\hline & Sig (2-talled) & 0,000 & & 0,158 & 0,052 & 0,033 & 0,060 & 0,019 & 0,002 & 0,000 \\
\hline & $\mathrm{N}$ & 14 & 14 & 14 & 14 & 14 & 14 & 14 & 14 & 14 \\
\hline \multirow[t]{3}{*}{ Oil Export } & Pearson Correlations & 0,641 & 0,398 & 1 & 0,550 & 0,647 & 0,678 & 0,643 & $-0,302$ & 0,667 \\
\hline & Sig (2-talled) & 0,013 & 0,158 & & 0,042 & 0,012 & 0,008 & 0,013 & 0,294 & 0,009 \\
\hline & $\mathrm{N}$ & 14 & 14 & 14 & 14 & 14 & 14 & 14 & 14 & 14 \\
\hline \multirow[t]{3}{*}{ Oil Import } & Pearson Correlations & 0,74 & 0,528 & 0,550 & 1 & 0,842 & 0,843 & 0,840 & $-0,570$ & 0,641 \\
\hline & Sig (2-talled) & 0,002 & 0,052 & 0,042 & & 0,000 & 0,000 & 0 & 0,033 & 0,013 \\
\hline & $\mathrm{N}$ & 14 & 14 & 14 & 14 & 14 & 14 & 14 & 14 & 14 \\
\hline \multirow[t]{3}{*}{ Oil Price (OPEC) } & Pearson Correlations & 0,802 & 0,571 & 0,647 & 0,842 & 1 & 0,988 & 0,995 & $-0,518$ & 0,637 \\
\hline & Sig (2-talled) & 0,001 & 0,330 & 0,012 & 0 & & 0,000 & 0 & 0,058 & 0,014 \\
\hline & $\mathrm{N}$ & 14 & 14 & 14 & 14 & 14 & 14 & 14 & 14 & 14 \\
\hline \multirow[t]{3}{*}{ Oil Price (US) } & Pearson Correlations & 0,745 & 0,513 & 0,678 & 0,843 & 0,988 & 1 & 0,971 & $-0,454$ & 0,587 \\
\hline & Sig (2-talled) & 0,002 & 0,060 & 0,008 & 0.000 & 0,000 & & 0 & 0,103 & 0,007 \\
\hline & $\mathrm{N}$ & 14 & 14 & 14 & 14 & 14 & 14 & 14 & 14 & 14 \\
\hline \multirow[t]{3}{*}{ Oil Price (Libya) } & Pearson Correlations & 0,842 & 0,616 & 0,643 & 0,840 & $-0,518$ & 0,971 & 1 & $-0,559$ & 0,684 \\
\hline & Sig (2-talled) & 0,000 & 0,019 & 0,013 & 0,000 & 0,058 & 0,000 & & 0,038 & 0,007 \\
\hline & $\mathrm{N}$ & 14 & 14 & 14 & 14 & 14 & 14 & 14 & 14 & 14 \\
\hline \multirow[t]{3}{*}{ Currency Rate } & Pearson Correlations & $-0,830$ & $-0,755$ & $-0,302$ & $-0,570$ & 0,518 & $-0,454$ & $-0,559$ & 1 & $-0,848$ \\
\hline & Sig (2-talled) & 0,000 & 0,002 & 0,294 & 0,033 & 0,058 & 0,103 & 0,038 - & & 0,000 \\
\hline & $\mathrm{N}$ & 14,000 & 14 & 14 & 14 & 14 & 14 & 14 & 14 & 14 \\
\hline \multirow[t]{3}{*}{ Stock Exchange Index } & Pearson Correlations & 0,958 & 0,841 & 0,667 & 0,641 & 0,637 & 0,587 & 0,684 & $-0,848$ & 1 \\
\hline & Sig (2-talled) & 0,000 & 0 & 0,009 & 0,013 & 0,014 & 0,027 & 0,007 & 0,000 & \\
\hline & $\mathrm{N}$ & 14 & 14 & 14 & 14 & 14 & 14 & 14 & 14 & 14 \\
\hline
\end{tabular}

Table 1: Correlation Test Macro Economic Indicators in Indonesia (2005-2010)

Global Fund Relationship with Financial Statements in Indonesia

The amount of incoming global funds (related to QE) then affects corporate financial strategies in Indonesia. It is important to observe these strategies to identify related behaviour patterns in the balance sheets and income statements of corporations in Indonesia. The correlation of growth (2007-2011) between accounts in the aggregate financial statements of public companies listed on the Indonesian stock exchange shows:

\begin{tabular}{|c|c|c|c|c|c|c|c|c|c|}
\hline & Correlation & |Liability & Gross Profit & Operating Expense & Operational Revenue & Other Income/Expense & Total Asset & Total Equity & Total Sales \\
\hline \multirow[t]{3}{*}{ Liability } & Pearson Correlation & 1 & \begin{tabular}{|r|}
0,426 \\
\end{tabular} & \begin{tabular}{|c|}
$-529(*)$ \\
\end{tabular} & 0,264 & $-0,114$ & $.8711^{(\star *)}$ & 0,503 & 0,408 \\
\hline & Sig. (2-tailed) & & 0,113 & 0,043 & 0,342 & 0,686 & 0,000 & 0,056 & 0,131 \\
\hline & $\mathrm{N}$ & 15 & 15 & 15 & 15 & 15 & 15 & 15 & 15 \\
\hline \multirow[t]{3}{*}{ Gross Profit } & \begin{tabular}{|l|} 
Pears on Correlation \\
\end{tabular} & 0,426 & 1 & $-.962^{(* *)}$ & $.947\left({ }^{(* *)}\right)$ & $-0,434$ & 0,481 & $.562\left({ }^{*}\right)$ & $\left..9577^{* *}\right)$ \\
\hline & Sig. (2-tailed) & 0,113 & & 0,000 & 0,000 & 0,106 & 0,070 & 0,029 & 0,000 \\
\hline & $\mathrm{N}$ & 15 & 15 & 15 & 15 & 15 & 15 & 15 & 15 \\
\hline \multirow[t]{3}{*}{ Operating Expense } & Pearson Correlation & $-.529(*)$ & $-962\left(^{* *}\right)$ & 1 & $-.822^{(*)}$ & $.517\left(^{*}\right)$ & $-0,504$ & $-0,474$ & $-952(* *)$ \\
\hline & Sig. (2-tailed) & 0,043 & 0,000 & & 0,000 & 0,048 & 0,055 & 0,075 & 0,000 \\
\hline & $\mathrm{N}$ & 15 & 15 & 15 & 15 & 15 & 15 & 15 & 15 \\
\hline \multirow[t]{3}{*}{ Operational Revenue } & Pearson Correlation & 0,264 & $.947\left(^{* *}\right.$ & $-.8222^{(*)}$ & 1 & $-0,293$ & 0,406 & $611\left(^{*}\right)$ & $.870^{(*)}$ \\
\hline & \begin{tabular}{|l|} 
Sig. (2-tailed) \\
\end{tabular} & 0,342 & 0,000 & 0,000 & & 0,289 & 0,133 & 0,015 & 0,000 \\
\hline & $\mathrm{N}$ & 15 & 15 & 15 & 15 & 15 & 15 & 15 & 15 \\
\hline \multirow[t]{3}{*}{ Other Income/Expense } & Pearson Correlation & $-0,114$ & $-0,434$ & $.517\left(^{*}\right)$ & $-0,293$ & 1 & $-0,015$ & 0,076 & $-.540\left(^{*}\right)$ \\
\hline & \begin{tabular}{|l|} 
Sig. (2-tailed) \\
\end{tabular} & 0,686 & 0,106 & 0,048 & 0,289 & & 0,958 & 0,787 & 0,038 \\
\hline & $\mathrm{N}$ & 15 & 15 & 15 & 15 & 15 & 15 & 15 & 15 \\
\hline \multirow[t]{3}{*}{ Total Asset } & \begin{tabular}{|l|} 
Pears on Correlation \\
\end{tabular} & $\mid .871^{(*)}$ & 0,481 & $-0,504$ & 0,406 & $-0,015$ & 1 & $.819\left(^{* \star}\right)$ & 0,361 \\
\hline & \begin{tabular}{|l|} 
Sig. (2-tailed) \\
\end{tabular} & 0,000 & 0,070 & 0,055 & 0,133 & 0,958 & & 0,000 & 0,186 \\
\hline & $\mathrm{N}$ & 15 & 15 & 15 & 15 & 15 & 15 & 15 & 15 \\
\hline \multirow[t]{3}{*}{ Total Equity } & Pears on Correlation & 0,503 & $.562\left(^{*}\right)$ & $-0,474$ & $\left.611^{*}\right)$ & 0,076 & $\mid 819\left({ }^{* *}\right)$ & 1 & 0,358 \\
\hline & Sig. (2-tailed) & 0,056 & 0,029 & 0,075 & 0,015 & 0,787 & 0,000 & & 0,190 \\
\hline & $\mathrm{N}$ & 15 & 15 & 15 & 15 & 15 & 15 & 15 & 15 \\
\hline \multirow[t]{3}{*}{ Total Sales } & Pearson Correlation & 0,408 & $.957\left(^{* *}\right)$ & $-.952^{(* *)}$ & $.870(*)$ & $-.540\left(^{*}\right)$ & 0,361 & 0,358 & 1 \\
\hline & Sig. (2-tailed) & 0,131 & 0,000 & 0,000 & 0,000 & 0,038 & 0,186 & 0,190 & \\
\hline & $\mathrm{N}$ & 15 & 15 & 15 & 15 & 15 & 15 & 15 & 15 \\
\hline
\end{tabular}

Table 2: Correlation Tests for Aggregate Growth Indonesia Public Company Financial Statements (2007 -2011) 
Asset growth is sustained by debt $(0.871)$ as well as by share capital increase (0.819). This indicates that during periods of capital inflow (such as triggered by the Fed's QE policy) companies in Indonesia grow through the use of financial markets (debt and stock). The correlation between the growth in assets, but the risks are almost equivalent is also evident from the pressure of debt of Gross Profit to Equity significant (0.562). This indicates the growth of the company's equity is also derived from the increase in retained earnings, which shows the presence of corporate efforts in Indonesia to change "hot money" in financial markets into a source of longer duration assets. A negative correlation between the debt position (liability) and Operating Expenses is also quite significant (-0.529). Global influence from QE from the Fed's policy will affect Indonesian banking. The FED makes Indonesian rupiah fluctuate in accordance with its policy direction. These policies would encourage the inflow of funds to developing countries that would then be immediately reversed when the policy turned toward the re-absorption of funds in the financial markets of developing countries. This leads to the potential destabilisation of "hot money" flowing quickly between countries.

The ability of banks to maintain liquidity is affected by the efficiency of the bank's risk management strategies in creating a foundation in business activities (Jasiene, 2012). In the end, banks make strategic decisions about their levels of risk and profit. The risk of losing the bank may have an impact on resources, income, and higher running costs that affects the operational costs and ultimately impact the capital adequacy of a bank (Jasiene, 2012). Only leverage that showed negative (0.00200) and significant (0.0226) effect to CAR. That is a very powerful external factor affecting the banking financial. A regression test showing results for Indonesian banks between 2002 and 2014 is shown in Table 3 below using EC2SLS. Baltagi and Liu (2009) give further explanations on the use of EC2SLS.

\begin{tabular}{|l|c|c|}
\hline VARIABLES & \multicolumn{2}{|c|}{ CAR (Capital Adequacy) } \\
\hline BI Rate & -677.9 & $(1,060)$ \\
\hline LDR & 3.294 & $(5.613)$ \\
\hline Lev & -0.00200 & $(0.0226)$ \\
\hline NPL & -114.3 & $(204.2)$ \\
\hline ROA & -0.0904 & $(3.926)$ \\
\hline Loan & 0.00632 & $(0.263)$ \\
\hline BOPO & -43.23 & $(52.02)$ \\
\hline Cash Ratio & 1.781 & $(6.114)$ \\
\hline NIM & 64.90 & $(116.7)$ \\
\hline
\end{tabular}

Table 3: Regression Test for Indonesia Monthly Banking Financial Statements (January 2002 December 2014). Number of banks = 102. BI Rate, Loan to Debt Ratio (LDR), Leverage, Net-performing loans (NPL), Return on Assets (ROA), Loan, ROA, Cash Ratio, Net Interest Margin (NIM) is an independent variable that is thought to affect Capital Adequacy (CAR).

Banks funding assets with debt thus resulted in leverage relationships with capital adequacy ratios (CAR) being negative. So it is evident that the Indonesian banking strategy map is very "reactive" to external factors. External factors can be influenced by domestic or foreign forces. Domestic forces would include factors such as inflation, while foreign forces would include the amount of foreign funds that are in Indonesia. 
Rizky I The Effect of The Fed's Quantitative Easing Policy

\section{Conclusions and Suggestions for Further Research}

Based on a simple correlation test which confirms the findings of previous studies, there is evidence that an important element in macroeconomic conditions in Indonesia is the pressure on the exchange rate. The exchange rate pressure is the result of the policy direction (rebalancing) of a global fund capital inflow triggered the Fed's Quantitative Easing policy. Identification of the sources of growth of accounts in the financial statements of public companies in Indonesia also indicated the strength of contextual issues related to global financial markets.

Indonesia companies utilize profit growth to increase the role of retained earnings in building the equity structure of the company. However, increasing debt is also used to build assets with corresponding pressures upon the operating costs of companies in Indonesia related to servicing this debt.

Indonesian banks funding assets with debt also results in less stable Capital Adequacy Ratios (CAR). So it is evident that the Indonesian banking strategy map is very "reactive" and is influenced by external factors such as global issues as well as by internal (enterprise performance issues).

More research is needed to examine data from both mainstream and social media on the pattern of stock price movement. Therefore, external triggers, such as global issues, and internal issues such as enterprise performance issues, can be mapped against each other in terms of their effect on Indonesian share prices. Where movement in share prices results from global issues (that cannot be influenced by the individual company), then this should be taken into account when considering corporate performance.

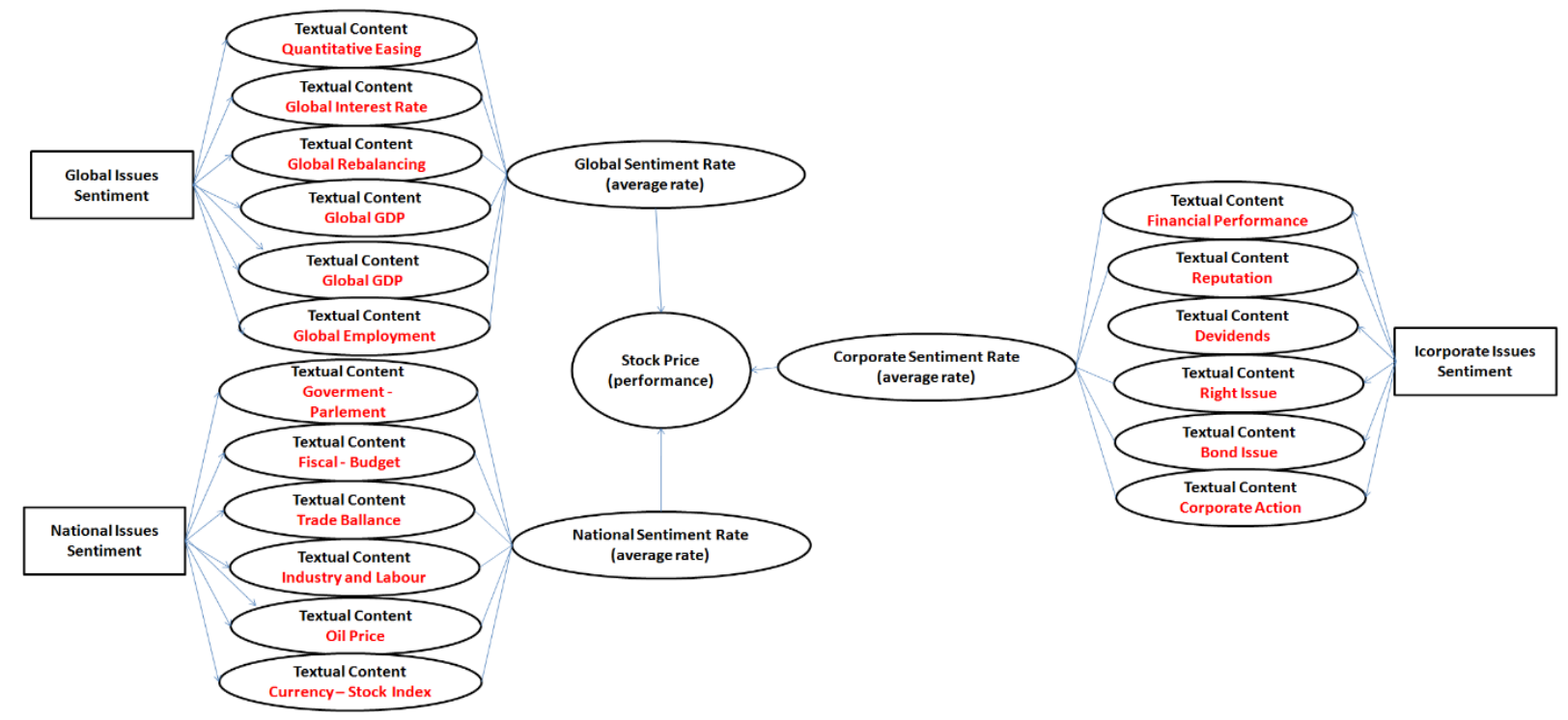

Figure 2: Model For Further Research 


\section{References}

Albanese, C., Li, D., Lobackeskiy, E. and Meissner, G. (2011). “A Comparative Analysis of Correlation Approaches in Finance”, Social Science Research Network, February.

Allen, F., and Santomero, A.M. (1997) "The Theory of Financial Intermediation”, Journal of Banking \& Finance, Volume 21, Issues 11-12, December 1997, pp.1461-1485. http://dx.doi.org/10.1016/s0378-4266(97)00032-0

Allen, F. and Gale, D. (2004). "Competition and Financial Stability”, Journal of Money, Credit, and Banking, Vol. 36, No. 3, The Ohio State University Press. http://dx.doi.org/10.1353/mcb.2004.0038

Angora, Alain, Caroline Roulet, Transformation Risk and its Determinants: A New Approach based on the Basel III Liquidity Management Framework, Université de Limoges, LAPE, 2011

Arora,Anju., Ownership Effects on Credit Risk, The IUP Journal of Financial Risk Management, Vol. X, No. 3, 2013.

Aspachs, Oriol, Erlend Nier, Muriel Tiesset., Liquidity, Banking Regulation, and the Macroeconomy: Evidence on Bank Liquidity Holdings from a Panel of UK-resident Banks, presentation at BIS www.bis.org/bcbs/events/rtf05AspachsNierTiesset.pdf, 2005

Baltagi, Badi H. and Liu, Long, "A Note on the Application of EC2SLS and EC3SLS Estimators in Panel Data Models" (2009). Center for Policy Research. Paper 50. http://surface.syr.edu/cpr/50

Bhattacharya, Sudipto, Anjan V. Thakor, Contemporarry Banking Theory, Jounal of Financial Intermediation 3, 2-50, 1993

http://dx.doi.org/10.1006/jfin.1993.1001

Berger, Allen N., Christa H.S. Bouwman, How does capital affect bank performance during financial crises?, Journal of Financial Economics 109 (2013) 146-176 Journal of Financial Economics, 146-176, 109, 2013 http://dx.doi.org/10.1016/j.jfineco.2013.02.008

Bessis, J. (2002). Risk Management in Banking. England:John Wiley \& Sons Ltd, Baffins Lane, Chichester, West Sussex.

Bikker, Jacob A., Measuring Performance of Banks: An Assessment, Journal of Applied Business and Economics vol. 11(4), 2010.

Camanho, A S., Dyson, R G., Cost efficiency, production and value-added models in the analysis of bank branch performance, The Journal of the Operational Research Society, May 2005. http://dx.doi.org/10.1057/palgrave.jors.2601839

Casarin, Roberto, and Flaminio Squazzoni."Being on the Field When the Game Is Still Under Way. The Financial Press and Stock Markets in Times of Crisis” PLOS One, Volume 8, July 2013 http://dx.doi.org/10.1371/journal.pone.0067721

Cohen, Benjamin H., and Michela Scatigna.Banks And Capital Requirements: Channels of Adjustment, Bank of International Settlement, BIS Working Papers No. 443, March 2014

Diamond, Douglas W., Philip H. Dybvig, Bank Runs, Deposit Insurance, and Liquidity, The Journal of Political Economy, vol. 91, no. 3, p. 401-19, The University of Chicago, 1983

Diamond, Douglas W., Raghuram G. Rajan, Banks and Liquidity, AEA meetings, 2001 
Rizky I The Effect of The Fed's Quantitative Easing Policy

Distinguin, Isabelle, Caroline Roulet, Amine Tarazi, Bank Capital Buffer and Liquidity: Evidence from US and European publicly traded Banks, Université de Limoges, March 2011

Economist, The. "Financial Economics: Efficiency and Beyond”, The Economist 392 (2009, July 18), 71-72

Goyal, Krishn A., Risk ManagementIn Indian Banks:Some Emerging Issues. Int. Eco. J. Res., 1(1) 102-109, 2010

Grondowski, G. H., \& Mahmood, M. The Relative Effectiveness Of Bail-Outs And Currency Controls: Financial Crisis Resolution In Malaysia and Indonesia. The Asia Pacific Journal of Economics \& Business, 12(1), 35-44,63, 2008.

Hardy, Daniel C., Phillip Hochreiter, A Simple Macroprudential Liquidity Buffer, IMF Working Paper, WP/14/235, International Monetary Fund, 2014

Harold, Lawrence., Thenmozhi, M., An Integrated Performance Success Measurement Framework For Evaluating Banking System Success: An Empirical Study, Journal of Performance Management, 25.3, 2014.

Hays, De Lurgio, and Gilbert Jr., Efficiency Ratios and Community Bank Performance, Efficiency Ratios and Community Bank Performance, Journal of Finance and Accountancy, Volume 1, 2009.

Hellwig, Martin., Systemic Aspects of Risk Management in Banking and Finance, Swiss Journal of Economics and Statistics, Vol. 131, 1995.

Ho, S.J. and S.-C. Hsu, Leverage, performance and capital adequacy ratio in Taiwan's banking industry. Japan and the World Economy, 2010.22(4): p. 264-272. http://dx.doi.org/10.1016/j.japwor.2010.06.007

Hopwood, Anthony G. Exploring the Interface Between Accounting and Finance, Accounting, Organizations and Society 34, 549-550, 2009.

http://dx.doi.org/10.1016/j.aos.2009.05.002

International Labour Office-ILO.Employment Challenges of Indonesian Economic Crisis. UN Developmet Programme, June. Jakarta:International Labour Office, 1998.

Jasiene, M., Martinavicius, J., Jaseviciene, F., \& Krivkiene, G. Bank liquidity risk: Analysis and estimates. Business, Management and Education, 10(2), 186-n/a., 2012

Kariastanto, Bayu Dwi. Blanket Guarantee, Deposit Indusrance, and Risk-Shifting Incentive: Evidence from Indonesia. Munich Personal RePEc Archieve (MPRA), 24, No.35557, 2011

Kashyap, Anil K., Raghuram Rajan, Jeremy C. Stein, Banks as Liquidity Providers: An Explanation for the Coexistence of Lending and Deposit Taking, The Journal of Finance, Vol. 57, No. 1, p. 33-73, Feb., 2002.

Klein, M.A. A Theory of the Banking Firm.Journal of Money, Credit and Banking, 3(2), 205-218, 1971

Komnenic, Biserka., Tomic, Radovan., Pokrajcic, Dragana., Intellectual Capital as A Valuable Driver of Corporate Performance: Empirical Research on The Banking Sector in Serbia, International Journal of Arts \& Sciences, p. 283-297, 2011.

Koch., MacDonald., Alternative Models of Bank Performance, South-Western, a division of Thomson Learning, 2003

Kyung, Chun Mun."Effects of Exchange Rate Fluctuations on Equity Market Volatility and Correlations: Evidence from the Asian Financial Crisis”,University of NebraskaLincoln, 2008

Liang, Yan. “Global Imbalances as Root Cause of Global Financial Crisis?” Journal of Economic Issues, Vol. XLV I, No. 1, March 2012

Mankiw, G. Macroeconomics. New York:Worth Publishers, 2009. 
Morgan, Peter J. "Impact of US Quantitative Easing Policy on Emerging Asia”, Social Science Research Network, November 2011

Moussetis, Robert C., Ali Abu Rahma., Nakos, George, Strategic Behavior and National Culturte: The Case of The Bangking Industry in Jordania, Competitiveness Review; Vol. 15-2, 2005.

OJK.Booklet Perbankan Indonesia 2014. Jakarta:OJK., 2014

Payant, W Randall, What's Corporate Performance Management and How Does it Fit the Banking Industry?, Journal of Performance Management, 3-13, 2006.

Polat, A., \& Al-khalaf, H. What determines capital adequacy in the banking system of kingdom of saudi arabia? A panel data analysis on tadawul banks. Journal of Applied Finance and Banking, 4(5), 27-43, 2014

Ramaswamy, Kannan., The performance impact of strategic similarity in horizontal mergers: Evidence from the U.S. banking industry, Academy of Management Journal; Vo. 403, Jun 1997. http://dx.doi.org/10.2307/257059

Repullo, Rafael, Capital requirements, market power, and risk-taking in banking, Journal of Financial Intermediation, Elsevier, vol. 13(2), p. 156-182, 2004 http://dx.doi.org/10.1016/j.jfi.2003.08.005

Rizky, Melissa. Analisis Kinerja Keuangan dengan Menggunakan Metode Camel: Studi Kasus Pada PT. Bank Sulselbar Tahun 2008-2010. Makassar: Universitas Hasanudin, 2012

Setyawan, A. A. (2011). Global crisis and country's competitiveness:: Lessons from indonesia and malaysia. European Research Studies, 14(3), 103-118.

Schäffer, Utz, Pascal Nevries, Christian Fikus, and Matthias Meyer. "Is Finance Research a "Normal Science"? A Bibliometric Study of the Structure and Development of Finance Research from 1988 to 2007”, Finance Research, sbr 63, April 2011

Siok, Kun Sek. "Interactions between Monetary Policy and Exchange Rate in Inflation Targeting Emerging Countries: The Case of Three East Asian Countries”, International Journal of Economic and Finance, Vol. 1, No 2, August 2009

Tambunan, T. The performance of small enterprises during economic crisis: Evidence from indonesia. Journal of Small Business Management, 38(4), 93-101, 2000

Tahir, Muhammad Naveed. "Inflation Targeting, Exchange Rate and Financial Globalization”GATE Groupe d’Analyse et de Théorie economique Lyon-St Étienne, November, 2012

Vaduva, Maria Alina, Strategy and strategic management in the Romanian banking system, Revista de Stiinte Politice Revue des Sciences Politiques,No. 37-38,2013

Vodova, Palva., Determinants of Commercial Banks Liquidity in Hungary, Acta academica karviniensia 1, 2011

von Thadden, Ernst-Ludwig, Marco Pagano The European Bond Markets under EMU, CSEF Working Papers 126, Centre for Studies in Economics and Finance (CSEF), University of Naples, Italy, 2004

Wong, J. et al. The Banking Sector in Hong Kong: Competition, Efficiency, Performance and Risk. England:Palgrave Macmillan Studies in Banking and Financial Institution, 159-171, 2008.

Wooldridge, Jeffry M., Introductory Econometrics A Modern Approach.4th Edition, South Western, a part of Cengage Learning, Canada, 2009

Yavas, Burhan F and Fisher, Dorothy M., Performance Evaluation of Commercial Bank Branches Using Data Envelopment Analysis, Journal of Business and Management,11.2, 2005. 